\title{
Sakarya'daki Iraklı ve Suriyelilerin Göç Süreçleri, Bütünleşme ve Gelecek Beklentileri
}

\begin{abstract}
Volkan YALÇIN ${ }^{1}$
Özet

Son yıllarda Türkiye'ye sınır komşusu olan devletlerde yaşanan siyasi gelişmelere bağlı olarak milyonlarca insan göç etmek zorunda kalmış ve bu göç dalgasından bugün dünyada en çok sığınmacıya ev sahipliği yapma unvanını taşıyan ülkemiz en fazla etkilenen ülke olmuştur. $\mathrm{Bu}$ çalışmada farklı disiplinler tarafından çalışılan mülteci ve sığınmacı konusu, coğrafi bir bakış açısı ile ele alınarak bu göçlerin kavramsal çerçevesi, göçün ana unsuru olan mekân değişiminin itici ve çekici faktörleri ile birlikte ela alınmış, bu göç sürecine katılan bireylerin, kentsel bütünleşme düzeyleri, Türkiye ve Sakarya'ya karşı olan bakış açıları ve geleceğe dönük beklentilerinin neler olduğu, Sakarya'da yaşayan Iraklı ve Suriyeli sığınmacılar örneğinden yola çıkılarak yapılan alan araştırması ile tespit edilmeye çalışılmıştır. Böylece sığınmacıların gelecek beklentileri belirlenerek politika üreticilerinin mevcut duruma ve geleceğe dönük kısa ve uzun vadeli planlamalarına katkı sağlanması amaçlanmaktadır.
\end{abstract}

Anahtar Kelimeler: Sığınmacı, Mülteci, Sakarya, Beşeri Coğrafya, Göç,

\section{Iraqi and Syrians in Sakarya Migration Processes, Integration and Future Expectations}

\begin{abstract}
In recent years, millions of people have forced to migrate due to the political developments in their states, which borders on Turkey. Our country, carries the title to host the most refugees in the world, has been the most affected country from this migration. Refugees and asylum seekers subject studied by different disciplines considering a geographical perspective, the conceptual framework of this migration, appealing and repelling of displacement, the main factor of the migration, colloborated in this study. By this field survey, it is tried to state individuals who participate in this migration process, their levels of urban integration, future expectations and perspectives to Turkey and Sakarya, based on the example of Iraqi and Syrian refugees living in Sakarya. Thereby, the future expectations of the asylum seekers are determined and it is aimed to contribute to the short and long term planning of the policy makers in the current situations and to the future.
\end{abstract}

Key Words: Asylum Seeker , Refugee, Sakarya, Human Geography, Migration

\footnotetext{
${ }^{1}$ Yüksek lisans öğrencisi, Sakarya Üniversitesi, Sosyal Bilimler Enstitüsü, Coğrafya Anabilim
} Dalı 


\section{Giriş}

Geçmişte olduğu gibi günümüzde de göç olgusu, göç eden kadar göç edilen coğrafi mekanda meydana getirdiği etkiler nedeniyle yerelden başlayıp, uluslararası ölçekte ele alınan bir kavram olarak önemini korumaktadır. Günümüzde iletişim, ulaşım, sermaye hareketliliği gibi birçok alanda yaşanan hızlı gelişmeler, sınırları ortadan kaldırarak dünyayı küçük bir köy haline getiriyormuş gibi görünse de süre gelen savaşlar, iç karışıklıklar ve terör olayları ile sosyo-ekonomik dengesizliklerin oluşturduğu tehdit algısı, konu insan hareketliliği olduğunda sınırların keskin çizgilerinin önemini korumasına yol açmaktadır. Buna rağmen bugün tüm dünya da 25,4 milyon mülteci, 40 milyon kendi ülkeleri içinde yerinden edilmiş kişi ve 3,1 milyon sığınmacı ile zorunlu göçe 68,5 milyon insan dahil olmuştur (UNHCR, 2018).

Türkiye bulunduğu coğrafi konumu ve bölgesindeki diğer ülkelere göre sahip olduğu sosyal ve ekonomik bir çok çekici faktörle birlikte, yakın çevresindeki ülkelerde yaşanan siyasi, sosyal ve ekonomik karışıklıkların yarattı̆ğ itici faktörlerin etkisi ile uluslararası bu göçlerin odak noktası konumuna gelmiştir. Bugün dünyada 3,6 milyonu geçici korumalı Suriyeli olmak üzere, 4 milyonu aşan göç etmiş insana ev sahipliği yaparak dünyada bu alanda birinci sırada yer alan ülke unvanına sahip olmuştur.

Çalışmamızın mekânsal olarak ana eksenini oluşturan Sakarya ilinde Şubat 2019 verilerine göre, ikamet iznine sahip (8,424 Kişi), koruma iznine sahip (11,235 Kişi) ve geçici koruma sahipleri (15,824 Kişi) olarak üç çeşit mülteci statüsü bulunmakta olup toplamda 35 bini aşan mülteci ikamet etmektedir. Bunların da büyük bölümünü Suriyeli ve Iraklı mülteciler oluşturmaktadır (Göç İdaresi Genel Müdürlüğü, 2018).

Mülteci kavramı, BM 1951 Cenevre Sözleşmesinde; “ 1rk1, dili, dini, milliyeti belli bir toplumsal gruba ait ya da siyasal görüşte olduğu için ülkesinde takibe uğrama korkusuyla ülke dışına çıkmış kişiler” şeklinde tanımlanmaktadır. Buna karşılık hükümetler gerçek mülteci ile yine onlara benzer durumdaki ancak vatanlarını terke zorlanmamış oldukları için mülteci tanımına uymayan göçmenler arasında ayrım yapmakta zorlanmaktadır (Tümertekin ve Özgüç, 2017: 311). Ülkemizde yurtdışından göç edenlere günlük yaşamda genel olarak "mülteci veya sığınmacı" kavramları kullanılmasına rağmen, hukuk sistemimizde mülteci kavramı 6458 sayılı "Yabancılar ve Uluslararası Koruma" kanununun 61. Maddesi uyarınca zorunlu sebeplerle sadece "Avrupa" dan gelen kişileri kapsamaktadır. Dolayısıyla BM'ler tanımına göre Suriyeli ve Iraklı mültecilerin göçe zorlanma nedenleri düşünüldüğünde ülkemizdeki statüleri mülteci olarak değerlendirilebilecekken, 6458 sayılı yasaya göre hukuki statüleri Avrupa kökenli olmamaları nedeniyle bunu engellemektedir.

2003'de Irak savaşı ile başlayan, Arap baharı ile Kuzey Afrika ve Ortadoğu'da devam eden ve en son 2010 yılında Suriye'ye sıçrayan savaş, Türkiye'ye doğru kitlesel göçlerin yaşanmasını tetikleyerek çok hızlı gelişen bu göç dalgasına karşı bir hukuki düzenlemeyi zorunlu kılarak 2014 
yılında yayınlanan 29153 sayılı Geçici Koruma yönetmeliği ile ülkesinden ayrılmaya zorlanmış ayrıldığı ülkeye geri dönemeyen acil ve geçici koruma amacıyla kitlesel olarak sınırlarımıza gelen ve sinırlarımızı geçen yabancılardan 6458 sayll yabancılar ve uluslararası koruma kanununa dahil edilmeyenleri kapsamına alarak bu statüde olanlara "geçici korumal yabancılar" statüsü verilmesini sağlamıştır. Mülteci olarak tanınmayan ve vatandaşı oldukları ülkeye, vatandaşlıkları yoksa mutat ikamet ülkesine dönemeyen veya geçerli kabul edilen sebeplerle dönmek istemeyen kişiler de facto mülteciler olarak ifade edilmektedir (Çiçekli, 2009:10). Görüldügü gibi uluslararası göçmenler kavramsal ve hukuki olarak farklı şekillerde tanımlanmakla birlikte bu çalışmada genel olarak çalışmaya konu yabancılar için, geçici korumalı ve sığınmacı kavramları kullanılmıştır.

Uluslararası göç kavramının çok boyutluluğu ve göç sürecinin karmaşık yapısı bugün birçok disiplinin ortak çalışma alanı olmasına neden olmuştur. Göçmen gruplar üzerinde yapılan yerel çalışmalardan elden edilen bulguların, bugün genel kabul gören göç teorileri ve stratejileri ile ilgili önemli birer kaynak oluşturduğu bilinmektedir. Sakarya'da yaşayan Iraklı ve Suriyeli sığınmacılar ölçeğinde yaptığımız bu çalışmada, Iraklı ve Suriyeli sığınmacıların göç süreçleri (göç nedenleri, itici, çekici faktörler, göçün tipi), Sakarya kenti özelinde kentsel bütünleşmeyi zorlaştıran ve kolaylaştıran etmenlerle birlikte mekânsal ve toplumsal aidiyet durumları ve son olarak da sığınmacılar için göçün kalıcılık durumu değerlendirilmeye çalışılmıştır. Çalışmanın eksenini sadece geçici korumalı Suriyelileri değil, aynı zamanda Iraklı sığınmacıları da kapsaması, göç kaynakları farklı olan bu iki grubun, göç süreçleri, bütünleşme, aidiyet ve göçün kalıcılık durumlarının karşılaştırmalı olarak değerlendirilmesini de sağlamıştır.

\section{1. Çalışmanın Amacı ve Yöntemi}

Yapılan literatür çalışmasında sığınmacı konusunda Türkiye'nin odak noktası haline gelmesi nedeniyle farklı disiplinler tarafından konunun özellikle sığınmacıların sosyal, ekonomik, psikolojik durum ve hukuki statülerine ilişkin boyutları ile ele alındıkları ve çalışmaların daha çok Suriyelilerin üzerinde yoğunlaştığı görülmüştür. Bu çalışma sadece geçici korumalı Suriyeli sığınmacıları değil, Iraklı sığınmacılar eksenini de içerisine alarak, sığınmacıları göçe iten ve Türkiye'ye çeken faktörlerin neler olduğu, kentsel bütünleşme düzeyleri ve geleceğe dair beklentilerinden yola çıkarak, bütüncül olarak göç sürecinin ortaya konulmasını hedeflemektedir. Böylece hukuki ve toplumsal statülerinde olduğu kadar coğrafi mekan içerisindeki statüleri de belirsizliğini koruyan sığınmacılarla ilgili politika üreticilere, STK'lara ve diğer ilgili paydaşlara fikir vereceği düşünülmektedir.

Çalışma alanı ve grubu olarak, Sakarya ilinde yaşayan 16 yaşından büyük eşit sayıda Iraklı ve Suriyeli toplam 100 kişiye 45 sorudan oluşan anket çalışması yapılmıştır. Türkçe olarak hazırlanan anketler, Arapçaya çevrilmiş ve alan taraması yapılarak, çevirmen gözetiminde birebir olarak uygulanmıştır. Anketin farklı sosyo-ekonomik özeliklere sahip eşit miktarda Suriyeli ve Iraklı 'ya uygulanması sağlanmıştır. Elde edilen veriler bir veri tabanı oluşturularak sistemleştirilmiş ve ilk 
olarak anket sorularına paralel olarak göç süreci, kentsel bütünleşme, aidiyet ve gelecek beklentileri kategorileri oluşturularak, bu kategorilere ait alt temalar, yapılan frekans ve yüzde analizleri ile değerlendirilerek sonuçları ortaya konulmuştur.

\section{2. Çalışma Grubunun Demografik ve Ekonomik Yapısı}

Alan çalışması sırasında uygulanacak anketlerin olabildiğince farklı demografik ve sosyoekonomik yapıdaki sığınmacılara ulaşılarak yapılması ve ortaya çıkacak sonuçların daha genel bir çerçeve çizebilmesi hedeflenmiş̧ir. Uygulanan anketlerin \%52'si kadın, \%48 ise erkek sığınmacılardan oluşmaktadır. TÜIK (2018) verilerine göre, Türkiye nüfusunun yaş ortalaması 31,7 olarak belirlenmiştir. Bu rakam Göç İdaresi'nin 2018 sığınmacı verilerinde ise Suriyeli sı̆̆ınmacılar özelinde 22,7 yaş ortalaması olarak ortaya çıkmakta ve sığınmacı yaş ortalamasının genç bireylerden oluştuğunu göstermektedir. (Göç İdaresi Genel Müdürlüğü, 2018)

Yaptığımız alan çalışmasında da bu duruma paralel bir durum ortaya çıkmış ve ankete katılanların \%78'i 15-35 yaş arasındaki genç bireylerden oluşmuştur. Ankete katılan sığınmacıların eğitim düzeyleri incelendiğinde her iki grubun da \%51'inin ortaokul ve lise mezunu oldukları, lisans ve yüksek lisans düzeyinde daha üst öğrenim almış olan birey ile okuryazar olmayan birey sayısında ise Iraklı ve Suriyeli sığınmacıların farklılaştıkları görülmüştür. Iraklı sığınmacıların üst öğrenim oranı \%12 ile daha yüksek iken, Suriyeli sığınmacılarda bu oranın \%6 olduğu, okuryazar olmayanların oranının yine Iraklı sığınmacılarda \%3 iken, Suriyeli sığınmacılarda \%9 olduğu görülmüştür.

Tablo 1: Ankete Katılanların Yaş ve Cinsiyet Yapısı

\begin{tabular}{|c|c|c|c|c|c|c|c|c|c|}
\hline & & \multicolumn{8}{|c|}{ Yaş } \\
\hline & & \multicolumn{2}{|c|}{$15-25$} & \multicolumn{2}{|c|}{$26-35$} & \multicolumn{2}{|c|}{$36-50$} & \multicolumn{2}{|c|}{50 ve Üzeri } \\
\hline & & Erkek & Kadın & Erkek & Kadın & Erkek & Kadın & Erkek & Kadın \\
\hline Geldiği & Irak & 11 & 16 & 3 & 5 & 1 & 5 & 5 & 4 \\
\hline \multirow[t]{2}{*}{ Ülke } & Suriye & 7 & 15 & 16 & 5 & 4 & 2 & 1 & 0 \\
\hline & & \multicolumn{2}{|c|}{$\% 49$} & \multicolumn{2}{|c|}{$\% 29$} & \multicolumn{2}{|c|}{$\% 12$} & \multicolumn{2}{|c|}{$\% 10$} \\
\hline
\end{tabular}

Ankete katılan Sakarya'daki Iraklı ve Suriyeli sığınmacıların kendi ülkelerindeki gelir seviyelerini gösteren Grafik 1 incelendiğinde Türkiye’ye geldikten sonra gelir seviyelerinde önemli bir düşüş yaşandığı ve özellikle bu gelir kaybının Iraklı sığınmacılarda gelir düzeyi yüksek olan grupta daha belirgin yaşandığı görülmektedir. Iraklı sığınmacıların \%40’1 kendi ülkelerinde 750 dolar ve üzerinde gelir elde ederken, Suriyeli sığınmacılarda ülkelerinde 750 dolar üstü kazananların oranı $\% 18$ 'dir. 
Grafik 1: Ankete Katılanların Ülkelerindeki ve Türkiye'deki Gelir Seviyeleri
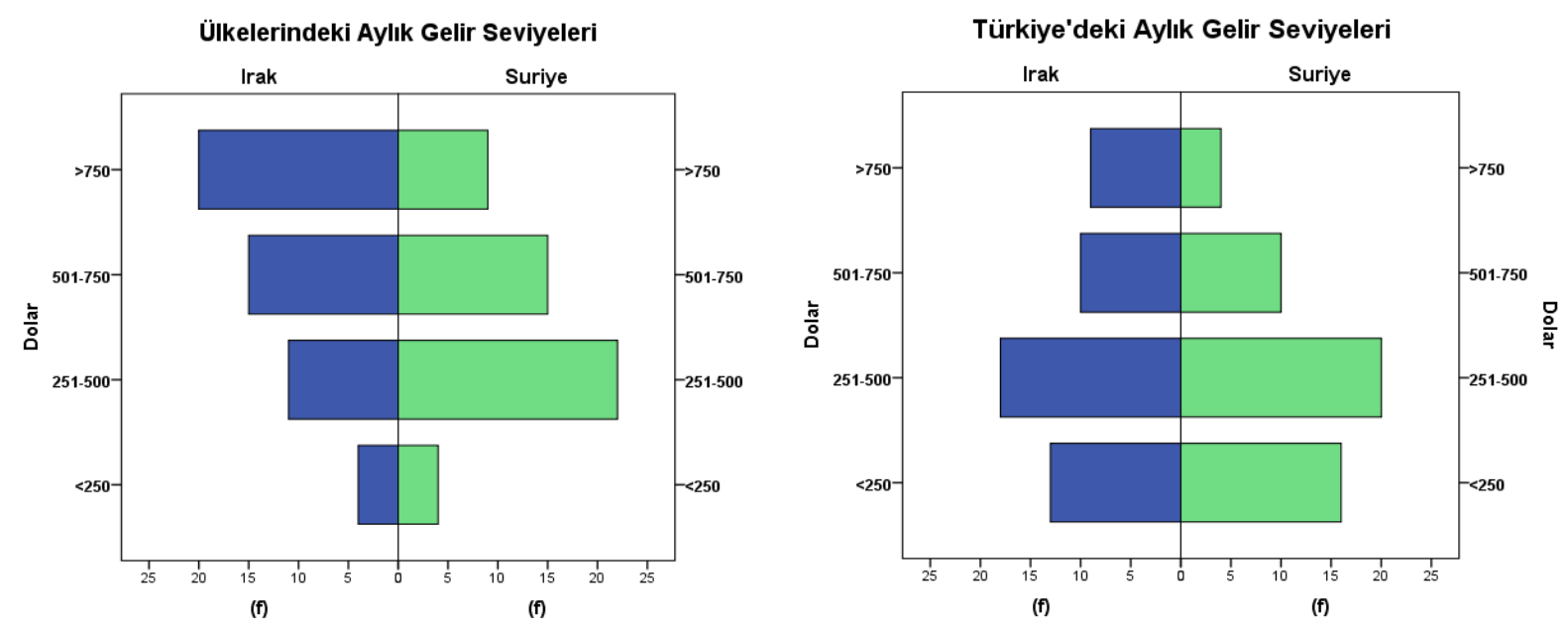

Kendi ülkelerindeki gelir seviyeleri açısından iki grup karşılaştırıldığında Iraklı sığınmacıların Suriyeli sığınmacılara göre ülkelerinde çok daha iyi gelir seviyesine sahip oldukları fakat iki grubun da Türkiye'ye geldiklerinde gelir seviyelerindeki dağılımın benzerlik gösterdiği görülmektedir. Ankete katılan Sakarya'daki Iraklı ve Suriyeli sığınmacıların \%29'u Türkiye'de aylık gelirlerinin 250 dolardan daha düşük olduğu belirtmişlerdir. Kendi ülkelerinde ise bu oran \%8'dir.

Bilindiği üzere dünyada ülkelerini terk eden göçmenlerin daha iyi bir refah seviyesi ve yaşam sahibi olma arzuları göç etme nedenleri arasında ekonomik nedenlerin de önemli bir yer tuttuğunu göstermektedir. Ancak savaş, iç karışıklık, terör gibi nedenlerle göçün ivedilikli, zorunlu ve kitlesel hale geldiği sığınmacılarda ise ekonomik faktörler çok daha geri planda kalmakta ve özellikle can güvenliği olan durumlarda, ülkelerindeki maddi varlıklar ve gelirler önemini yitirebilmektedir. Sığınılan ülkede ise karşılaşılan olası sorunların en başında bu kez geçim ve ekonomik sorunlar yeni bir engel olarak baş edilmesi gereken bir problem kaynağı oluşturmaktadır.

Ankete katılan sığınmacıların Sakarya'daki geçim yöntemleri sorulmuş ve Tablo 2'de görüleceği üzere \%50'sinin çalışarak bir gelir elde ederken, geriye kalan \%17'lik kısmın kendi birikimleri ile \% 25'inin ise bireysel ve kurumsal yardımlarla geçindikleri tespit edilmiştir.

Tablo 2: Ankete Katılanların Sakarya'daki Geçim Şekli

\begin{tabular}{|l|c|c|c|c|}
\hline Hedef Ülkedeki Geçim Şekli & \multicolumn{2}{|c|}{ Geldiği Ülke } & \multirow{2}{*}{ (f) } & (\%) \\
\cline { 2 - 4 } & Irak & Suriye & & \\
\hline Çalışıyorum & 24 & 26 & 50 & 50 \\
Kendi birikimlerim & 10 & 7 & 17 & 17 \\
Aile/Çevre Yardımları & 8 & 7 & 15 & 15 \\
Kurum/Devlet Yardımları & 3 & 7 & 10 & 10 \\
Diğer & 5 & 3 & 8 & 8 \\
\hline Toplam & 50 & 50 & 100 & 100,0 \\
\hline
\end{tabular}




\section{Göç Süreci; İtici ve Çekici Faktörler}

İnsanların yaşam alanlarını terk ederek, göçe katılmasına neden olan faktörler ve göç süreci bugün farklı disiplinlerin üzerinde durduğu çalışma konuları arasında yer almaktadır. Göç etme nedenlerindeki farklılıklar, birçok mikro ve makro ölçekli göç teorisi ve modelinin ortaya atılmasına neden olmuştur. Everet Lee (1966) 'nin ileri sürdüğü ve göçün; İtici, çekici ve kişisel etmenler ile araya giren engellerden oluşan dört temel tarafindan şekillendiği görüşüne dayanan ve makro göç yaklaşımı olan itme-çekme modeli, göç süreçlerini tetikleyen ana unsurları genel anlamda anlamamıza yardımcı olmaktadır. (Everet Lee,1966:50-51)

Göç nedenleri göze alınarak birçok itici ve çekici faktör sıralanabilir. İtici güçler arasında çevresel, demografik, ekonomik ve siyasal baskılar sayılabilir. Göçmenleri belirli bir varış yerine çeken çekici güçler ise, genellikle itici güçlerin tersi olan güçlerin sonucudurlar; Yaşama koşullarını iyileştirmek için ekonomik fırsatlar, kişisel güvenlik, özgürlük ve bağımsızlık şansı ile eğitim ve kültürle ilgili firsatlar gibi toplumsal olanaklardır (Tümertekin ve Özgüç, 2017: 296).

Çalışmamıza konu olan sığınmacıların temelde zorunlu olarak göç etmiş olmaları elbette isteğe bağlı olan göçlerdeki gibi bir göç sürecini içermesi beklenemez. Özellikle Iraklı ve Suriyeliler arasında göç sürecinde belirgin bir farklılık olup olmadığını tespit etmek, göçü tetikleyen itici faktörleri ve çekici faktörleri belirlemek, bu iki farklı grubun göç süreçlerindeki farklılıklarını dikkate almak, doğru politikalar ve yaklaşımlar geliştirilmesi açısından önem arz etmektedir.

Sakarya'daki Iraklı ve Suriyeli sığınmacıların Tablo 3'de verilen kaynak ülkelerinden ayrılma nedenleri incelendiğinde her iki grubu da göçe iten faktörlerin paralellik gösterdiği görülmektedir. Ankete katılanların \%75'i güvenlik, savaş ve terör korkusu ile ülkelerini terk etmiştir. \%11'lik oranla Dini/Mezhepsel baskının en önemli ikinci itici faktör olması, aynı zamanda ilgili grupları Türkiye’ye çeken faktörlerin de şekillenmesinde belirleyici olmuştur. Görüldügü üzere bugün özellikle ülke içi göçlerin en büyük nedeni olarak gösterilen ekonomik nedenler, güvenlik endişeleri nedeniyle zorunlu göçe katılan sığınmacılar için geri planda kalmaktadır.

Tablo 3: Ankete Katılanların Ülkelerinden Ayrılma Nedenleri (itici Faktörler)

\begin{tabular}{|l|r|r|r|r|r|}
\hline \multirow{2}{*}{ Kaynak Ülkeden Ayrılma Nedeni } & \multicolumn{2}{|c|}{ Geldiği Ülke } & \multirow{2}{*}{ (f) } & (\%) & Kümülatif (\%) \\
\cline { 2 - 5 } & Irak & \multicolumn{1}{|c|}{ Suriye } & \\
\hline Siyasi Baskı & 0 & 2 & 2 & 2,0 & 2,0 \\
Dini/Mezhepsel Baskı & 6 & 5 & 11 & 11,0 & 13,0 \\
Güvenlik/Savaş/Terör & 39 & 36 & 75 & 75,0 & 88,0 \\
Ekonomik Neden & 1 & 3 & 4 & 4,0 & 92,0 \\
Diğer & 4 & 4 & 8 & 8,0 & 100,0 \\
\hline Toplam & 50 & 50 & 100 & 100,0 & \\
\hline
\end{tabular}


Kaynak ülkelerden ayrllş̧ta temelde güvenlik endişesi yatmakla beraber bu güvenlik sorununun oluşmasını tetikleyen alt nedenler arasında her iki ülkede de yaşanan mezhepsel çatışmalarının olduğu da unutulmamalıdır. Alan çalışması sırasında yapılan birebir görüşmelerde, her iki grubun da özellikle mezhep ve rejim konularına ilişkin çekinceli oldukları, cevap vermekte çekindikleri gözlemlenmiştir. Dolayısıyla ilgili grupların farklı mezhep ve inanç yapılarında olabilecekleri ve bu konuda yerel halkın ve diğer ilgili paydaşların da bilgili olması ve hassas davranması sağlanmalıdır.

Göç sürecinin önemli unsurlarından birisi de göçün sonucunda varılan hedef ülke ve o ülkedeki çekici faktörlerin yanı sıra coğrafi engeller (çöl, dă̆ vb.) toplumsal, kültürel ve siyasi risk ve tehditlerin varlığı oluşturmaktadır. Irak ve özellikle Suriye savaşı ile Türkiye’ye yaşanan göç akımında da birçok faktörün etkili olduğu bilinmektedir. Bunların başında Türkiye'nin özellikle Suriyeli sığınmacılara karşı uyguladığı “açık kapı” politikası büyük önem teşkil etmektedir. Bu durum Türkiye'nin bugün dünyada en fazla sığınmacı bulunduran ülke olması için yeterli bir genel açıklama gibi görünse de, kaynak ülkeden hedef ülkeye yönelmiş göçe katılan bireyler için her zaman tek bir neden ile göç sürecini açıklamak yeterli olmayacaktır. Tablo 4'de ankete katılan Suriyeli sığınmacılar için açık kapı politikasının (girişlerin kolaylı̆̆l/sınırların açık olması) çekici faktörler arasında kendi algılarında önemli bir faktör olmadığı görülmektedir.

Göç akımlarını etkileyen en önemli faktörlerden bir tanesi göçe konu olan kaynak ve hedef ülkeler arasındaki mesafe ya da başka bir deyişle coğrafi yakınlıktır. Ravenstein'in (1885 ve 1889) göçlerle ilgili olarak ileri sürdüğü bir dizi kural arasında en önemlisi olan “mesafe” kuralına göre gidilecek mesafe göçmen sayısı ile ters orantılıdır (akt. Tümertekin ve Özgüç, 2017: 297). Özellikle yoksul olan göçmenler için yolculuğun mesafesi ile maliyeti arasındaki ilişki gidilecek yerin tayininde önemli bir rol oynamaktadır.

Yaptığımız anket çalışmasında gerek Iraklı gerekse Suriyeli sığınmacıların Türkiye’yi seçmelerinde \%24'lük oranda kültürel ve dini yakınlı̆̆n ve yine \%24'lük bir oranla coğrafi (mekânsal) yakınlığın önemli bir paya sahip olduğu görülmektedir. Tablo 4 incelendiğinde Suriyeli sığınmacıların Türkiye'yi seçmelerinde coğrafi (mekânsal) yakınlığın Iraklı sığınmacılara göre daha önemli bir çekici faktör olduğu görülmektedir. Suriye'de gerçekleşen olayların ve güvenlik sorunlarının ani olarak gelişmesi, özellikle sosyo-ekonomik düzeyleri düşük olan Suriyeli ailelerin mesafe faktörünü dikkate almasına ve Türkiye, Lübnan ve Ürdün’e yönelmelerine neden olmuştur. 
Tablo 4: Ankete Katılanların Türkiye’yi Seçme Nedenleri (Çekici Faktörler)

\begin{tabular}{|c|c|c|c|c|c|}
\hline \multirow[t]{2}{*}{ Hedef Ülkeyi Seçme Nedeni } & \multicolumn{2}{|c|}{ Geldiği Ülke } & \multirow[b]{2}{*}{$(f)$} & \multirow[b]{2}{*}{$(\%)$} & \multirow[b]{2}{*}{ Kümülatif (\%) } \\
\hline & Irak & Suriye & & & \\
\hline Coğrafi Yakınlık & 10 & 14 & 24 & 24 & 24 \\
\hline Kültürel ve Dini Yakınlık & 11 & 13 & 24 & 24 & 48 \\
\hline Özgür ve Demokratik Bir Ülke Olması & 14 & 8 & 22 & 22 & 70 \\
\hline Akraba ve Tanıdıkların Varlığı & 5 & 6 & 11 & 11 & 81 \\
\hline Giriş Kolaylığı/Sınırların Açık Olması & 5 & 3 & 8 & 8 & 89 \\
\hline Başka Ülkelerin Almaması & 5 & 6 & 11 & 11 & 100 \\
\hline Toplam & 50 & 50 & 100 & 100,0 & \\
\hline
\end{tabular}

Göç etme nedenleri (itici faktörler) aynı olsa bile, hedef ülkeyi seçme konusunda (çekici faktörler) sığınmacılar için farklı bakış açıları, stratejiler ve farklı kriterler etkili olabilmektedir. Iraklı ve Suriyeli sığınmacıların Türkiye'yi seçme nedenleri arasında \%22'lik oranla özgür ve demokratik bir ülke olması da önemli bir yer tutmaktadır. Özellikle Iraklı sığınmacılar için Türkiye'nin özgür ve demokratik bir ülke olması, çekici faktörler arasında önemli ölçüde tercih nedeni olarak görülmekte ve bu anlamda Suriyeli sı̆̆ınmacılardan anlamlı biçimde ayrılmaktadırlar.

$\mathrm{Bu}$ durumu anket uygulanan Iraklı ve Suriyeli grupların kendi ülkelerindeki gelir düzeylerini gösteren Grafik 1 ile ilişkilendirdiğimizde, gelir seviyeleri daha iyi olan Sakarya'daki Iraklı sığınmacıların güvenli bir bölge arayışları kadar, göç ettikleri ülkede, daha iyi ve özgür bir yaşam arayışı içerisinde olmaları anlam bulacaktır. İkincil olarak bu cevabın her iki grup için farklılaşması ankete katılan sığınmacıların Türkiye'yi özgür ve demokratik bir ülke olarak algılama düzeyleri ile de ilgili olabilir düşüncesini akla getirmektedir. Ankette yer alan Türkiye çağdaş ve özgür bir devlettir? İfadesine ankete katılanların \%63 katılıyorum, \%24 ise kesinlikle kat1lıyorum cevabı vererek, gerek Iraklı gerekse Suriyeli katılımcıların büyük bir bölümünün Türkiye’yi çağdaş ve özgür bir devlet olarak değerlendirdikleri görülmektedir. Bu da hedef ülkenin çekici faktörlerinin her göçmen için aynı önem ve değere sahip olmadığını göstermesi açısından önem taşımaktadır.

Göçmen ağları, Massey vd., (1998') tarafından "akrabalık, arkadaşlık ve ortak kökenli topluluk bağları aracılı̆̆ıyla, köken ve hedef alanlardaki göçmenleri, eski göçmenleri ve göçmen olmayanları birbirine bağlayan kişiler arası bir topluluk" olarak tanımlanmaktadır. Ankete katılanların \%11'lik bölümü Türkiye'yi ve Sakarya'yı seçmelerinde etkili olan çekici faktörler arasında akraba ve tanıdıklarının varlığının etkili olduğunu belirtmiştir. Bu durum göçmenler arasında organize olma ve yeni göçmen ağları kurulmaya devam edeceğini de göstermektedir. Sakarya'daki sığınmacıların hem ikamet yeri seçiminde, hem de ticari anlamda açtıkları dükkânlarla özellikle belli semtlerde ve alanlarda yoğunlaşmaları da bu göçmen ağlarının bir sonucu olarak değerlendirilmelidir. 


\section{Türkiye ve Sakarya ile Bütünleşme}

Uluslararası göçlerde kaynak ülkelerden gelenler ile hedef ülkelerdeki bireylerin birbirleriyle karşılaşmalarının bir sonucu olarak kültürel, mekânsal ve psikolojik değişimler ile birlikte yeniden bir kültürleşme süreci yaşanacağı bilinmektedir. Bu süreç içinde göçmenler ile yerel halk arasında karş1lıklı olarak gelişecek tutum ve davranışlar bütünleşme ve kültürleşme sürecinin seyrini belirleyen en önemli unsurlardır.

Bu konuda Göregenli ve Karakuş (2014:103) 'un kültürel ve mekânsal bütünleşmeyi konu alan çalışmalarında, Berry'nin (1997; 1998; 1999) farklı etnik ve kültürel grupların kültürleşme sürecinde kullandıkları stratejilerden bahsedilerek; "Bireyler, kendi kültürel kimliklerini sürdürme yanlısı olmayıp, diğer kültürlerle etkileşime girmeye istekli oldukları durumda asimilasyon stratejisini kullanmaktadırlar. Separasyon/Ayrılma stratejisi ise, bireylerin kendi kültürel kimliklerini korumaya önem verirken, diğerleriyle etkileşimden kaçındıkları durumları ifade etmektedir. Entegrasyon/ Bütünleşme stratejisi, bireylerin hem kendi kültürel kimliklerini sürdürmeye hem de diğerleriyle günlük etkileşime önem verdikleri durumu ifade etmektedir. Marjinalleşme ise, kültürel sürekliliği sağlamaya yönelik düşük düzeyde çaba ve isteğin olduğu ve diğerleriyle etkileşime çok az önem verildiği durumu ifade etmektedir” şeklinde aktarılmıştır.

Türkiye'deki başta geçici korumalı Suriyeliler olmak üzere yasal olarak mülteci statüsüne kavuşamamış uluslararası sığınmacılara yönelik, kısa ve uzun vadede uygulanacak politikaların ve geleceğe dönük planlamaların net olarak bilinmemesi, diğer taraftan ise göçe ev sahipliği yapan yerli halk tarafından bu farklı etno-kültürel yapıdaki grupların geçici misafir olarak algılanmaları, kültürel bütünleşmenin sağlanmasını geciktirmektedir. Bu durum göçmen grupların zamanla ayrılma ya da marjinalleşme eğilimlerinin artmasına yol açma riski taşımaktadır. Suriye'de ve Irak’ta devam eden siyasi sorunların belirsizliğini korumaya devam etmesi kısa vadede geri dönüşlerin mümkün görünmediğini göstermekte ve kültürel bütünleşmenin gerekliliğinin her geçen gün biraz daha öneminin artırmasına neden olmaktadır.

Sığınmacıların ilk başta kendi içlerindeki göçmen ağları ile sınırlı tutmaya çalıştıkları kapalı yaşantılar ve kendi kültürel kimliklerini korumaya dönük ayrılma stratejileri zaman içerisinde bütünleşmeyi kolaylaştırıcı etmenler (toplumsal kabul, ortak kültürel değerler vb.) ile kırılmaya uğrayabileceği gibi, yerel halkın olumsuz tutumları ve diğer bütünleşmeyi zorlaştırıcı etmenler (iletişim sorunu, ötekileştirme, ters kültürel değerler vb.) ile daha fazla tetiklenerek bütünleşmenin zorlaşması ve sığınmacı grupların marjinalleşme eğilimine girmesine, beraberinde etnik ve kültürel çatışmaların yaşanmasına sebebiyet verebilir. Bu kapsamda Sakarya'daki Iraklı ve Suriyeli sığınmacıların bu bütünleşmeye karşı tutumlarının ne olduğu ve kültürel bütünleşmeye ne kadar açık oldukları, bütünleşmenin kolaylaşstırıcı etmenleri ile zorlaştırıcı etmenlerinin yanı sıra mekânsal memnuniyet düzeyleri özelinde ele alınmıştır. Sakarya halkına karşı geliştirdikleri olumlu ya da 
olumsuz algı düzeylerinin ölçülmesi adına geliştirilen anket soruları ile bütünleşmenin kolaylaştırıcı ve zorlaştırıcı etmenleri tespit edilmeye çalışılmıştır.

Katılımcılara yöneltilen ve Grafik 2 'de gösterilen "Sakarya halkı sıcakkanlı ve misafirperverdir" sorununa, \%26'sı kesinlikle katılıyorum, \%43'ü katılıyorum cevabını vermiştir. Kesinlikle katılmıyorum diyen \%10'luk ve katılmıyorum diyen \%8'lik bölümün ise daha çok Suriye kökenli sığınmacılar olduğu görülmektedir. Bu durum, yerel halkın Suriyeli sığınmacılara karşı yaklaşımlarının farklılık gösteriyor olabileceğini akıllara getirmektedir.

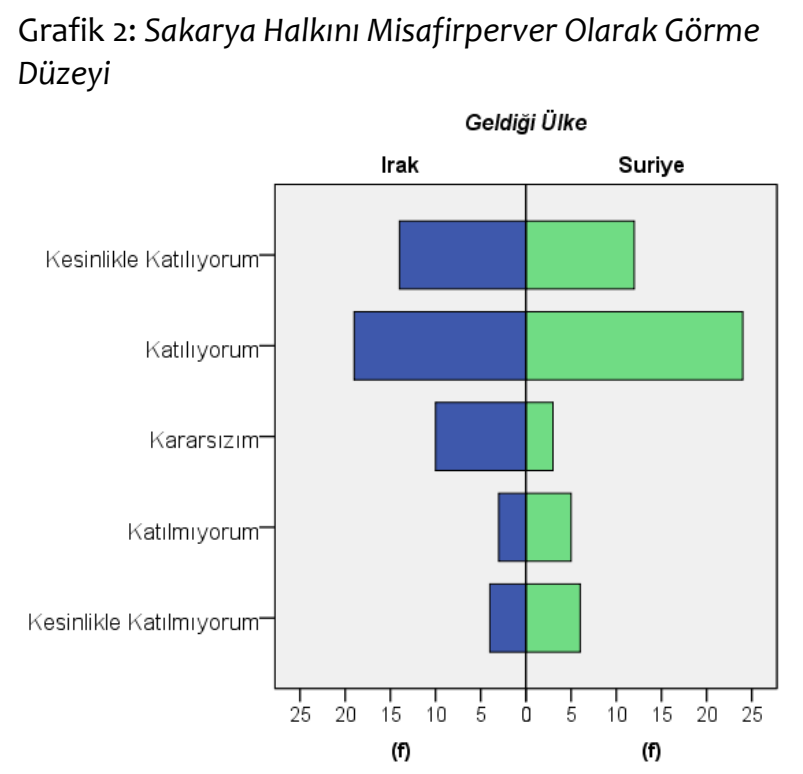

\section{Grafik 3: Sakarya Halkını Kültürel Olarak Yakın Görme Düzeyi}

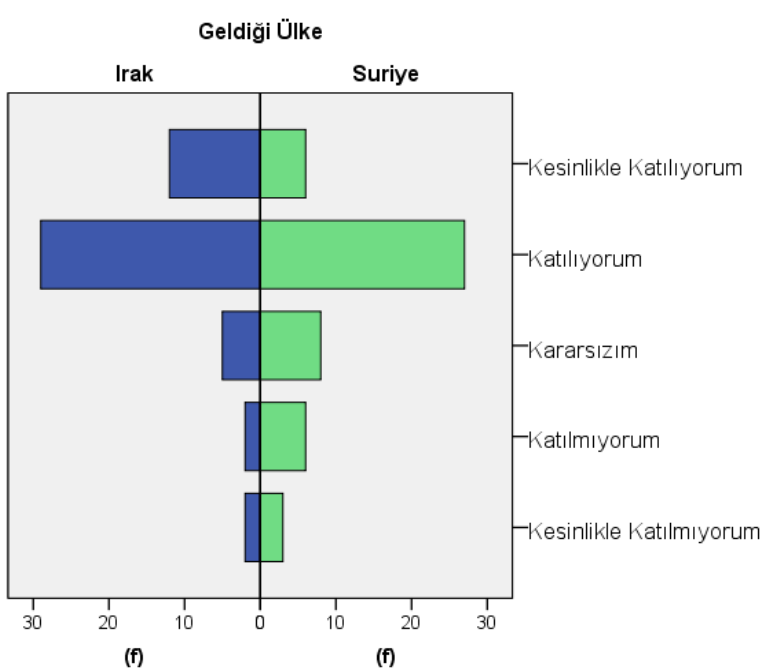

Sığınmacılar ile hedef ülke/bölgenin yerel halkı arasındaki kültürel benzerlikler de bütünleşmeyi kolaylaştıran etmenler arasında önemli bir yer tutmaktadır. Grafik 3' de "Sakarya halkını kültürel olarak kendime yakın görüyorum" sorusuna katılımc1ların \%18'i kesinlikle katılıyorum, \%56'sı ise katılıyorum cevabını vermiştir. Bu olguya karşı çıkarak kesinlikle katılmıyorum diyenlerin $\% 5$ ve katılmıyorum diyenlerin oranının ise $\% 8$ olduğu görülmüştür. Daha önce Tablo 4'te de Türkiye'yi seçme nedenleri arasında dini ve kültürel yakınlığın önemli bir yer tuttuğu (\%24) ankete katılanlar tarafından ifade edilmiştir.

Görüldüğü üzere sığınmacıların Sakarya'daki yerel halka ve kültürel benzerliğe karşı büyük oranda olumlu yönde bütünleşmeyi kolaylaştırıcı tutum ve algıya sahip oldukları görülmektedir. Göç eden ve göç alan grubun bir arada yaşamaya açık olmaları, karşılıklı uyum ve uzlaşma sağlamaları bütünleşme açısından önem taşımaktadır. Bu nedenle de kültürel çeşitliliğe sahip olan yerlerde göçmenlerin bütünleşme sergilemeleri daha olası görülmektedir. (Turut ve Özgür, 2018: 158). Sakarya ili geçmişte göç ve göçmen tecrübelerini yaşamış ve bünyesinde Kırım, Balkan ve Kafkasya kökenli göçmenleri barındırmanın yanı sıra, iç göçlerin de önemli çekim merkezlerinden birisi olma özelliği nedeniyle farklı kültürel değerleri bünyesinde taşımaktadır. Sahip olduğu bu özellik gelen göçmenlerin 
de tutum ve davranışları ile kültürleşme ve bütünleşme sürecini kolaylaştırabilecek etmenler arasında değerlendirilebilir.

Kültürel benzerlikler içerisinde özellikle aynı dili konuşan, aynı dine inanan grupların birbirine karşı tutumlarının olumlu yönde daha kolay geliştiği görülmektedir. Bu konuda Montreuil ve Bourhis (2001), yaptıkları bir çalışmada, Kanada'nın Quebec bölgesinde yaşayan, anadili Fransızca olan üniversite öğrencilerinin, ev sahibi topluluk olarak Fransa'dan gelen göçmenlere ilişkin, kabullenme eğilimlerinin daha yüksek olduğunu; Haiti'den gelen göçmenlere ilişkin ise asimilasyoncu, ayırmacı ve dışlayıcı eğilimlerinin daha yüksek olduğunu ortaya koymuşlardır. (Montreuil ve Bourhis, 2001: 710). Bugün Türkiye'de sığınmacıların büyük bölümünün Suriye sınırımızdaki Kilis, Hatay, Şanlıurfa gibi illerimizde yoğunluk göstermesinde mekansal yakınlıkla beraber, dil özelinde kültürel yakınlığın da etkisinden kaynaklanmaktadır. Diğer taraftan ise dil ve iletişim sorunları bütünleşmeyi zorlaştıran bir unsur olarak karşımıza çıkabilmektedir.

Sığınmacıların Sakarya'da ve Türkiye'de karşılaştıkları en önemli sorun alanları daha önce yapılan çalışmalardan yola çıkarak 7 farklı kategoride sınıflandırılarak, sığınmacılar için en önemli sorun alanı/alanlarının neler olduğu tespit edilmeye çalışılmıştır. Tablo 5 incelendiğinde sığınmacıların en önemli sorununun \%45 ile iletişim/dil sorunu olduğu görülmektedir. İletişim sorununun kültürel ve kentsel bütünleşmedeki önemi düşünüldüğünde bütünleşmenin zorlaştırıcı faktörleri arasında yer aldığı görülmektedir. İkincil olarak karşılaşılan en önemli sorunun \%26 ile iş bulma/işsizlik olduğu tespit edilmiştir. Sı ğınmacıların iş bulma konusunda da temelde dil probleminin önemli bir yer tuttuğu unutulmamalıdır.

Yapılan alan çalışmasında özellikle kentin ortak ve yoğun ticaret alanlarında bulunan birçok dükkânın, Suriyeli ve Iraklı sığınmacıları çalıştırdığı görülmüştür. İlk bakışta ucuz iş gücü temini olarak değerlendirilebilecek bu durum, yapılan mülakatlar sırasında farklı bir boyutun da varlığını ortaya çıkartmıştır. İşveren esnafin yanlarında Iraklı ve Suriyeli çalıştırması diğer sığınmacıların alışveriş sırasında dil/iletişim problemi yaşamasını çözerek sığınmacıların alışverişlerinde bu esnafları tercih etmesinde etkili olmuştur. 
Tablo 5: Sakarya'daki Sığınmacıların Türkiye ve Sakarya'da Karşılaştıkları Sorunlar

\begin{tabular}{|l|c|c|c|c|}
\hline \multirow{2}{*}{ Hedef Ülkedeki Karşılaşılan Sorun Alanları } & \multicolumn{2}{|c|}{ Geldiği Ülke } & \multirow{2}{*}{ (f) } & (\%) \\
\cline { 2 - 4 } & Irak & Suriye & & 26 \\
\hline İş bulma/Işsizlik & 11 & 15 & 26 & 45 \\
Illetişim/Dil & 23 & 22 & 45 & 2 \\
Eğitim & 2 & 0 & 2 & 4 \\
Sağlık & 3 & 1 & 4 & 4 \\
Barınma/Konut Sorunu Giriş & 3 & 1 & 4 & 7 \\
Ötekileştirilme/Kabul Görmeme & 4 & 3 & 7 & 9 \\
Yardımların Yetersizliği & 3 & 6 & 9 & 3 \\
Diğer & 1 & 2 & 3 & 100,0 \\
\hline Total & 50 & 50 & 100 & 4 \\
\hline
\end{tabular}

Şan ve Koçlu (2018:12) da Sakarya'daki mültecilerin iletişim sorunlarına ilişkin yaptıkları bir çalışmada da sığınmacıların en önemli sorunlarının iletişim/dil, barınma ve işsizlik olduğunu tespit etmişlerdir. Yine aynı çalışmada Sakarya'daki sığınmacıların dil bilmemekten kaynaklı olarak toplumsal yaşamda en çok sağlık, eğitim ve sosyal hayat alanlarında sorun yaşadıkları belirtilmiştir.

Sı ̆̆ınmacıların göç ettikleri mekanları benimsemeleri ve mekana ilişkin aidiyet hissetmeleri, kalıcılık düzeyleri üzerinde doğrudan etkili olan bir faktördür. Kentin sunduğu firsatlardan yararlanabilme, mülk edinme ve kentte kalma süresinin uzaması gibi nedenler aidiyet duygusunun gelişmesi üzerinde belirleyicidir. Bir taraftan yeni mekana uyan göçmenler aidiyet duygusu kazandıkça eski alışkanlıkları ve kültürlerine ait değerlerle mekanı yeniden şekillendirme eğilimine de girebilmektedir.

Mekansal aidiyet duygusunun gelişmesi göçmenlerin yaş yapısı ile de ilişkilidir. Yaşlı göçmenlerin geldikleri mekanlarda daha fazla yaşantı ve deneyime sahip olmaları, göç edilen yeni mekanı kabul etmelerini zorlaştırırken, göç edilen yerde doğan genç nesillerde ise bu mekana karşı aidiyet daha yüksek olmaktadır. İnsanların yeni yerleştikleri bir çevreye ilişkin ilk algıları dar bir alanda, özellikle komşuluk ilişkileri ile şekillenmeye başlamakta, sokağa karşı güven duygusu arttıkça mekânsal etkileşime geçtikleri alanlarda genişleyerek kentin sunduğu fursatlara ulaşma imkanlarının artmasını sağlamaktadır. Böylece mekan ile birey arasında kurulan karşılıklı güven ve güvene dayalı etkileşim, yer kimliği ve yere bağlllık gibi kavramlarla da ifade edilen mekânsal aidiyet duygusunu geliştirmektedir.

Yaptığımız çalışmada ankete katılan sığınmacıların ailesi için çevreyi güvenli görme düzeylerinin tespit edilmesine yönelik olarak "Ailem sokağa çıktı̆̆ında endişe duyuyorum” sorusu yöneltilmiş ve katılımcıların \%31 kesinlikle katılmıyorum, \%38'i ise katılmıyorum cevabını vererek kentsel çevreye olan güvenlerinin büyük oranda geliştiğini ortaya koymuşlardır. Kentsel çevreye olan 
güven duygusu Iraklı ve Suriyeli sığınmacılar özelinde ele alındığı Grafik 4 'de Suriyeli sığınmacıların Iraklı sığınmacılara göre daha kararsız ve güvensiz oldukları görülmektedir.
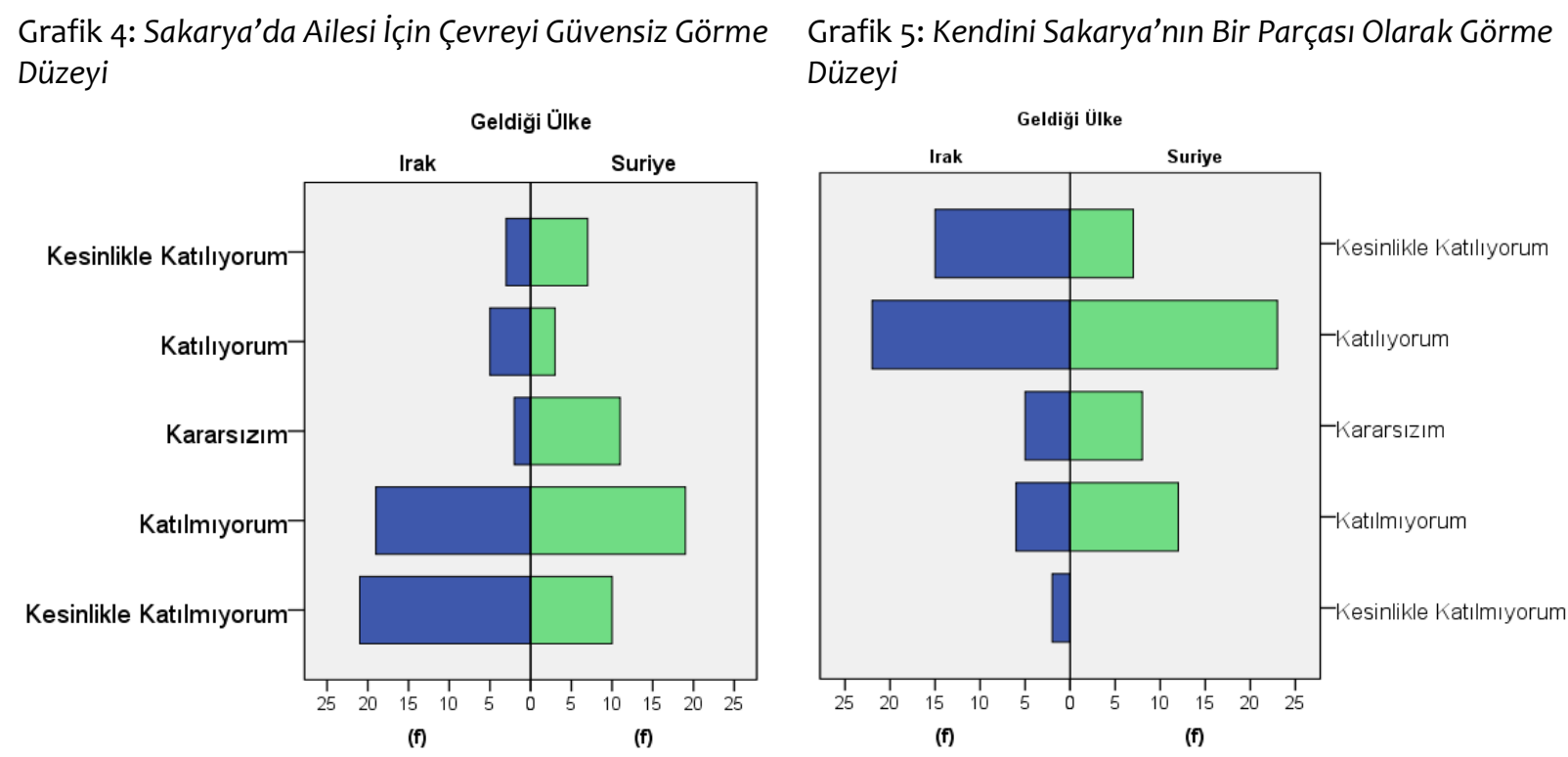

Yaptığımız ankete katılan sığınmacılara yöneltilen “Kendimi Sakarya'nın Bir Parçası Olarak Görüyorum" sorusuna \%22'si kesinlikle kat1lıyorum, \%45'i katılıyorum cevab1 vermiştir. Yine katılımcıların \%13'ü kararsız olduğunu belirtirken, \%18'i katılmadığını, \%2'si ise kesinlikle katılmadığını belirtmiştir. Grafik 5 incelendiğinde Suriyeli katılımcıların yine Iraklı katılımcılara göre mekânın parçası görme ve aidiyet konusunda daha kararsız ve çekinceli durdukları görülmektedir.

Sadece Suriyelilere yönelik yapılan benzer bir çalışmada Türkiye'yi vatan olarak görme durumları tespit edilmeye çalışılmış \%60’1 vatan olarak görürken, \%23'ü ikisini de (Suriye ve Türkiye) vatan olarak gördüğünü belirtmiştir. (Demirbaş vd., 2018: 259).

Genç ve Alsancak (2018:477) 'ın Suriyeli sığınmacılar özelinde yaptıkları anket çalışmasında; Suriyeli katılımc1ların Sakarya'da olmaktan mutluyum ifadesine kat1lımc1ların \%35'inin kesinlikle katılıyorum, \%42'sinin katılıyorum, \%21'inin kararsızım yanıtını verdiklerini, Sakarya'da yaşamaktan dolayı mutlu olmayan kesimin ise sadece $\% 2$ olduğu belirtmişlerdir.

Elbette ki savaştan ve güvensiz bir ortamdan ani ve zorunlu bir göçle gelen Suriyeli sığınmacıların Sakarya'da mutluluk düzeylerinin yüksek ya da kendilerini kentin bir parçası olarak görmeleri mutlu olunan yere bağlanmayı kolaylaştıracak önemli bir kriterdir. Fakat mekânsal aidiyetin tam olarak gerçekleştiği ve kültürel bütünleşmenin sağlandığını da tek başına açıklamak için yeterli olmayacaktır. Bu tarz çalışmaların sayısının artması, sığınmacıların kalma sürelerindeki artışla birlikte düşünüldüğünde farklı sonuçlar verebilecek ya da çok yönlü bakış açılarının gelişmesine katk1 sağlamaya devam edecektir. 


\section{Türkiye ve Sakarya'da Göçün Kalıcılığı, Gelecek Beklentisi}

Türkiye'deki sayıları her geçen gün artan sığınmacılarla ilgili olarak gerek kamuoyunda gerekse toplumda en önemli gündemin sığınmacıların kalıcılı̆̆ı ve gelecekte kendi ülkelerine dönüp dönmeyecekleri sorunu olduğu bilinmektedir. Sığınmacıların menşei ülkelerinde siyasi ve toplumsal sorunların devam etmesi, Türkiye'de yöneticilerin bu konuda kesin bir politik görüş ve hedef belirtmemesi/belirtememesi ve yine Avrupa Birliği gibi uluslararası örgütlerin Suriyeli mülteciler özelinde Türkiye'ye yeteri kadar destek sağlamaması sığınmacı belirsizliğini derinleştirmektedir.

Yaptığımız çalışmada, 6458 sayılı Yabancılar ve Uluslararası koruma kanunu ve 2014 yılında yayınlanan Geçici Koruma Yönetmeliği ile statüleri bir nebze de olsa hukuki olarak belirlenmeye çalışılan sığınmacılar açısından, Türkiye'de kalıcı olma ve geleceğe dair kendi beklentilerinin ne olduğu da tespit edilmeye çalışılmıştır.

TÜİK (2018) verilerine göre, ülkemizde son 2015-2018 dönemlerinde toplamda en fazla konut satışı yapılan grubun Irak uyruklu yabancılar olduğu görülmektedir. Menşei ülkesi bilinmemekle birlikte Sakarya ili 1366 konut ile 2018 yılında Türkiye'de yabancılara en çok konut satışı yapılan altıncı şehir konumundadır. (TÜIK,2018) Kalıcılıkla ilgili en önemli göstergelerden bir tanesi mülk edinimidir. Çalışmamızda sığınmacılara yöneltilen “Türkiye'de/Sakarya'da mülk edinmeyi/yatırım yapmayı düşünürüm" sorusuna verilen cevaplar Tablo 6'da incelendiğinde Iraklı sığınmacıların, Suriyeli sığınmacılara göre mülk edinimi konusunda daha istekli oldukları, ankete katılan Suriyelilerin ise $\% 35$ 'inin bu konuda kararsız, toplam \%38'inin ise katılmıyorum ve kesinlikle katılmıyorum cevabı verdikleri görülmüştür. Bu farklılaşmanın temelinde ikamet ve koruma izinli Iraklı ve geçici korumalı Suriyeli sığınmacıların mülk edinme konusundaki hukuki statülerinin farklılık göstermesinin de etkili olduğu düşünülmektedir.

Tablo 6: Sakarya'daki Iraklı ve Suriyeli Sığınmacıların Mülkiyet Edinmeye Isteklilik Düzeyleri

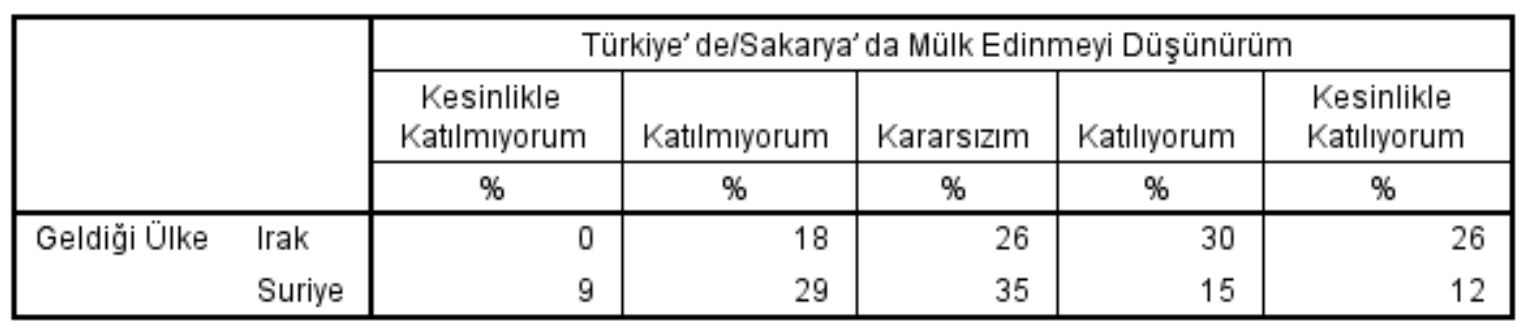

Sığınmacıların geleceğe dönük göç stratejilerini belirleyecek en önemli dış etmen, geldikleri ülkelerde göçe neden olan itici faktörlerin ortadan kalkıp kalkmayacağıdır. Bu konuda ankete katılan sığınmacılara “ülkemde yakın gelecekte sorunların biteceğine inanıyorum” sorusu yöneltilmiştir. Tablo 7 incelendiğinde her iki menşei ülkeye ait sığınmacıların da sorunların biteceği ile ilgili inanç düzeylerinin genel anlamda kararsız ve düşük olduğu görülmüştür. Bu belirsizlik sürecinin göç stratejilerini geliştirmeleri ve bütünleşme süreçleri üzerinde etkili olduğu unutulmamalıdır. 
Tablo 7: Menşei Ülkede Yaşanan Sorunların Yakında Biteceğine Inanma Düzeyleri

\begin{tabular}{|c|c|c|c|c|c|c|}
\hline & \multicolumn{5}{|c|}{ Ülkemde Yakın Gelecekte Sorunların Biteceğine İnanıyorum } \\
\hline & & $\begin{array}{c}\text { Kesinlikle } \\
\text { Katılmıyorum }\end{array}$ & Katılmıyorum & Kararsızım & Katılıyorum & $\begin{array}{l}\text { Kesinlikle } \\
\text { Katılıyorum }\end{array}$ \\
\hline & & $(\%)$ & $(\%)$ & $(\%)$ & $(\%)$ & $(\%)$ \\
\hline \multirow[t]{2}{*}{ Geldiği Ülke } & Irak & 34 & 20 & 24 & 6 & 16 \\
\hline & Suriye & 28 & 10 & 32 & 18 & 12 \\
\hline
\end{tabular}

Sığınmacıların Türkiye'de kalmaya istekli olma düzeylerini ölçmek için yöneltilen “ülkemdeki sorunlar bitse bile Türkiye'de kalmayı düşünüyorum" sorusuna verilen cevaplar Tablo 8'de incelendiğinde Iraklı sığınmacıların \%62'sinin kesinlikle katılıyorum ve katılıyorum cevabını verdiği, bu konuda daha istekli oldukları görülmüştür. Suriyeli sığınmacıların toplamda \%44’ü katılıyorum ve kesinlikle katılıyorum cevabı verirken \%38'lik bir bölümünün ise kararsız oldukları görülmüştür. Her iki grupta da kesinlikle katılmıyorum diyenlerin oranı ise sadece \%2' dir. Sığınmacıların Türkiye'de kalıcı olmaya genel anlamda istekli oldukları tespit edilmiştir. Bununla beraber kararsızım cevabını verenler üzerinde hem menşei ülkedeki sorunlara hem de Türkiye'deki statülerine ilişkin belirsizliğin devam etmesinin etkili olduğu düşünülmektedir.

Tablo 8: Menșei Ülkede Sorunlar Bittiğinde Türkiye’de Kalmaya İstekli Olma Düzeyleri o

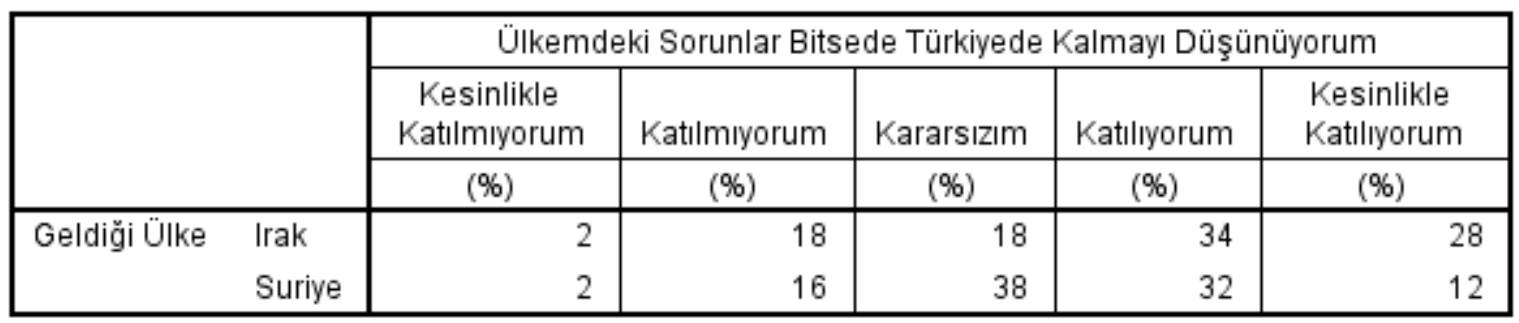

Her iki gruptaki sığınmacıların statülerini ve belirsizliklerini giderecek olan vatandaşlık hakk1 verilmesi konusunda istekli olma düzeylerinin benzer olduğu görülmüştür. Tablo 9 incelendiğinde "Türkiye Cumhuriyeti vatandaşlığına geçmek isterim" sorusuna, Iraklı sığınmacıların toplamda \% 82'si katılıyorum ve kesinlikle katılıyorum cevabını vermiştir. Suriyeli sığınmacılar ise toplamda \%76 oranında katılıyorum ve kesinlikle katılıyorum cevabını vererek Türkiye'de kalıcı olma beklentisinde olduklarını göstermişlerdir. Elbette vatandaşlık hakkı konusunda sığınmacıların beklentileri kadar, yerli halkın da bu konudaki tutum ve algıları büyük önem taşımaktadır. Yöneticilerin bu toplumsal dinamikleri de, en az sığınmacıların beklentileri kadar dikkate almaları gerekmektedir. 
Tablo 9: Türkiye Cumhuriyeti Vatandaşlığına Geçmeye İstekli Olma Düzeyleri

\begin{tabular}{|c|c|c|c|c|c|c|}
\hline & & \multicolumn{5}{|c|}{ Türkiye Cumhuriyeti Vatandaşığına Geçmek İsterim } \\
\hline & & $\begin{array}{l}\text { Kesinlikle } \\
\text { Katılmıyorum }\end{array}$ & Katılmıyorum & Kararsızım & Katılıyorum & $\begin{array}{l}\text { Kesinlikle } \\
\text { Katılıyorum }\end{array}$ \\
\hline & & $(\%)$ & $(\%)$ & $(\%)$ & $(\%)$ & $(\%)$ \\
\hline \multirow[t]{2}{*}{ Geldiği Ülke } & Irak & 0 & 12 & 6 & 38 & 44 \\
\hline & Suriye & 0 & 16 & 8 & 30 & 46 \\
\hline
\end{tabular}

Çiftçi (2018:2251) 'nin Türkiye Cumhuriyeti vatandaşlarının Suriyeli sığınmacılara yönelik tutum, alg1 ve empati eğilimlerine ilişkin yaptığı çalışmada ankete katılan yerli halkın Suriyelilere karşı olumsuz ön yargıya, tutum ve algıya sahip olmamakla beraber, Suriyelilere vatandaşlık hakkı verilmesi ve birlikte yaşama konularında daha olumsuz tutum ve algıya sahip oldukları saptanmıştır Görüldüğü üzere her iki araştırmanın sonuçları karşılaştırıldığında bu konuda sığınmacılar ile yerli halkın karşılıklı olarak beklenti, algı ve tutumları uyuşmamaktadır.

Iraklı ve Suriyeli sığınmacıların kaynak ülkelerine geri dönüş ve kalıcılık konusunda genel olarak benzer bir tutum içerisinde olduklarını söylemek mümkündür. Tablo 10'da görüleceği üzere çalışmada sı̆̆ınmacılara yöneltilen "gelecek 5 yl içerisinde planınız nedir?" sorusuna beş kategoride cevap verme imkanı tanınmıştır. Her iki gurupta da \%48'lik bir bölümün öncelikli planlarının/hedeflerinin Türkiye Cumhuriyeti vatandaşlı̆ğ almak/ Türkiye’ye yerleşmek olduğu sonucuna ulaşılmıştır. Ülkesine geri dönmek isteyenlerin oranı ise toplamda \%18 olup Suriyelilerin kendi ülkelerine geri dönmeye Iraklı katılımcılara göre daha istekli oldukları görülmüştür. Türkiye'yi bir basamak olarak kullanarak göçün kademeli olarak bir Avrupa ülkesine doğru gerçekleşmesine istekli olan ve bir Avrupa ülkesine yerleşmek isteyenlerin toplam oranı \%18 olarak belirlenmiştir. Avrupa'ya yerleşme konusunda Suriyeli katılımcıların Iraklı katılımcılara göre daha istekli oldukları ortaya çıkmıştır. Katılımcıların başka bir İslam ülkesine yerleşmek konusunda ise istekli olmadıkları görülmektedir.

Tablo 10: Gelecek 5 yıl liçerisindeki Hedefleri/Planları

\begin{tabular}{|c|c|c|c|c|c|c|}
\hline & \multicolumn{5}{|c|}{ Gelecek 5 Yıl İçerisindeki Hedefiniz/PIanınız Nedir? } \\
\hline & & $\begin{array}{c}\text { Türk } \\
\text { vatandaşlığı } \\
\text { almak/Yerleş } \\
\text { mek }\end{array}$ & $\begin{array}{l}\text { Ülkeme geri } \\
\text { dönmek }\end{array}$ & $\begin{array}{l}\text { Kararsızım/Bil } \\
\text { miyorum }\end{array}$ & $\begin{array}{l}\text { Bir Avrupa } \\
\text { Ülkesine } \\
\text { Yerleşmek }\end{array}$ & $\begin{array}{l}\text { Başka Bir } \\
\text { İslam } \\
\text { Ülkesine } \\
\text { Yerleşmek }\end{array}$ \\
\hline & & (\%) & (\%) & (\%) & (\%) & (\%) \\
\hline \multirow[t]{2}{*}{ Geldiği Ülke } & Irak & 48 & 12 & 30 & 6 & 4 \\
\hline & Suriye & 48 & 24 & 6 & 22 & 0 \\
\hline
\end{tabular}




\section{Sonuç}

Göç, mekânsal hareketlilik ve mekânsal değişikliklere yol açma etkisi ile coğrafi bir boyuta sahiptir. Göçün kaynak ülkesi ile hedef ülke arasında gerçekleşmiş olması göç sürecinin tamamlandığı anlamına gelmemektedir. Göçe katılanlar, kendilerini süreç içerisinde yeni duruma karşı geliştirdikleri göç stratejileri ile değiştirdikleri gibi gittikleri mekanda da değişikliklere yol açmaktadırlar.

Büyük kentlerin bilindik sosyo-ekonomik farklılıklara dayalı olan ağırlıklı sosyo-mekânsal farklılaşma biçiminin uluslararası göçmenler (yeni azınlı grupları) ile değişime uğrama olasılığını artırıyor. Böylece Türkiye kentlerinin yakın gelecekteki yeniden yapılanma biçimlerinde sosyomekânsal ayrışmanın yeni belirleyicilerinden biri olmaya aday gözüken "uluslararası göçmen statüsü” nün yer edinme olasılığı gittikçe güçleniyor (Yüceşahin, M.M. , 2017: 1314).

Sakarya'daki Iraklı ve Suriyeli sığınmacılar ekseninde ele alınan çalışmamızda, iki gurubun göçe iten nedenlerinin büyük oranda benzerlik gösterdiği, buna karşılık Iraklı sığınmacıların Türkiye'yi seçmelerinde coğrafi/kültürel/dini yakınlığın dışında Suriyeli sığınmacılardan farklı olarak Özgürlük ve Demokrasi arayışlarının da önemli bir yer tuttuğu saptanmıştır. Yine sığınmacılar arasında göçmen ağlarının geliştiği ve bu göçmen ağlarının menşei ülkelerden yeni göç hareketlerinde etkin olarak kullanılabileceği görülmektedir.

Sığınmacıların Türkiye'de ve Sakarya özelinde kentsel ve kültürel bütünleşmeye açık oldukları ve bu konuda yerel halka karşı olumlu tutum ve algı içerisinde oldukları tespit edilmiştir. Bununla beraber başta iletişim/dil sorunu ve işsizliğe bağl1 ekonomik sorunların varlığı bütünleşmeyi engelleyici faktörler olarak karşımıza çıkmaktadır. Sığınmacıların özellikle toplumsal hayatın önemli noktaları olan sağlık, eğitim alanları ile etkileşimde oldukları kamu kurum ve kuruluşlarında yaşadıkları iletişim problemlerinin çözümüne yönelik olarak bu alanlarda yetkin kişilerin istihdam edilmesi büyük önem taşımaktadır. Ayrıca gençlere yönelik dil eğitimlerinin yaygınlaşması için STK, yerel yönetimler ve kamu kurum ve kuruluşlarının etkinliğini artırması gerekmektedir.

Iraklı ve Suriyeli sığınmacıların geleceğe ve Türkiye'deki kalıcı olmaya dönük beklentilerinin genel anlamda benzerlik gösterdiği, kendi ülkelerinde sorunların biteceğine karşı inançlarının düşük olmakla birlikte, bu sorunların son bulması durumunda da Türkiye'de kalmaya istekli oldukları tespit edilmiştir. İki grubun cevaplarında en yüksek benzerliğin, vatandaşlık hakkı verilmesine dair beklentilerinde olduğu görülmüştür. Ancak bu konuda yerel halkın aynı tutum ve beklentiye sahip olmadığı yapılan diğer çalışmalarda görülmektedir. Sığınmacılara vatandaşlık verme ve birlikte yaşama konusunda, yerli halkın olumsuz yaklaşımı bu konuda atılacak siyasi adımların ve alınacak kararların hassasiyetle ele alınması gerektiğini ortaya koymaktadır.

Sığınmacıların yakın geleceğe dair göç stratejileri ve planları içerisinde vatandaşlık hakkı almanın önemli bir yer tuttuğu tespit edilmiştir. Iraklı ve Suriyeli sığınmacıların ülkelerine geri dönmek veya Türkiye'den ayrılarak başka bir Avrupa ülkesine gitmek konusunda farklı bakış açılarına 
sahip oldukları, Suriyelilerin geri dönmek veya kademeli olarak başka bir ülkeye geçmek konusunda daha istekli oldukları tespit edilmiştir. Ancak Türkiye'de geçirdikleri sürecin uzaması, toplumsal ve mekânsal bütünleşmeyi zorunlu kılacak ve yer bağlılı̆ğın artıracaktır. Bu durum geriye dönme ya da başka ülkelere geçme konusundaki isteklerinin zamanla azalmasına neden olacaktır. Diğer taraftan sığınmacıların toplumsal ve mekânsal statülerinin netleşmemesinin yaratabileceği bir etki de, zorunluluk haline gelmeye başlayan toplumsal bütünleşme sürecini olumsuz etkileyerek, sığınmacı grupların ayrılma ve marjinalleşme eğilimine girmelerine ve toplumsal çatışma risklerinin artmasına neden olabileceğidir.

Karmaşık, çok yönlü ve aynı zamanda uluslararası boyutu ile toplumsal, akademik ve siyasi gündemde önemini koruyan göç ve sığınmacılar konusunda, Türkiye sahip olduğu tarihsel göç tecrübelerinin de ışığında, çok yönlü politikalar geliştirmek mecburiyetindedir. Çalışmamızda Iraklı ve Suriyeli sığınmacıların birçok konuda farklılaştıkları görülmüştür. Bu nedenle genelde ve yerelde geliştirilecek politikaların farklı menşei ülkeye mensup sığınmacılar özelinde ele alınması ayrıca önem taşımaktadır. 


\section{Kaynakça}

Çiftçi, Hasan (2018). "Türkiye Cumhuriyeti Vatandaşlarının Suriyeli Sığınmacılara Yönelik Tutum, Algı ve Empatik Eğilimlerinin Analizi”, İnsan ve Toplum Bilimleri Araştırmaları Dergisi, 7 (3), 2232-2256.

Çiçekli, Bülent (Ed.) (2009). Göç Terimleri Sözlüğü. İsviçre: Uluslararası Göç Örgütü (IOM )

Demirbaş, Çağrı Öztürk, Yurdal Dikmenli ve İbrahim Gafa (2018). "Türkiye'de Geçici Koruma Altındaki Suriyelilerin Vatan Algısına İlişkin Görüşleri”, Sosyal Bilimler Araştırmaları Dergisi, 13 (2), 253-266.

Genç, Yusuf ve Fatmanur Alsancak (2018). "Suriyeli Sığınmacıların Uyum Sorunlarının Sosyal Hizmet Perspektifinde Değerlendirilmes”,. Düzce 1. Uluslararası Göç ve Mülteci Kongresi.(23-25 Kasım 2017). Düzce Üniversitesi.

Göç İdaresi Genel Müdürlüğü. (2018). http://www.goc.gov.tr/icerik/goc-istatistikleri_363_378 (E.t. 05.03.2019)

Göregenli, Melek ve Pelin Karakuş (2014). "Göç Araştırmalarında Mekân Boyutu: Kültürel ve Mekânsal Bütünleşme”, Türk Psikoloji Yazıları, 17 (34), 101-115.

Lee, Everett S. (1966). A Theory Of Migration. Demography, 3(1), 47-57.

Massey, Douglas, Graeme Hugo, Adela Pellegrino, Joaquin Arango, Ali Kouaouci (1998). Worlds In Motion: Understanding International Migration At The End Of The Millennium. Oxford: Oxford University Press.

Montreuil, Annie ve Richard Y. Bourhis (2001). "Majority acculturation orientations toward valued and devalued immigrants", Journal of Cross-Cultural Psychology, 32, 698-719.

Şan, Filiz ve Seda Koçlu (2018). "Sakarya'daki Mültecilerin İletişim Sorunlarının Belirlenmesi ve Toplum Çevirmenliğine Olan İhtiyaç”, İnternational Journal of Language Academy, 6 (4), 1-16.

Turut, Hatice ve E. Murat Özgür (2018), "Bir Kente Göçün Hikayesi: Süreçler, Bütünleşme ve Aidiyet", Ankara Üniversitesi, TÜCAUM, Coğrafi Bilimler Dergisi. 16(1), 153-180.

Tümertekin, Erol ve Nazmiye Özgüç (2017). Beşeri Coğrafya İnsan Kültür Mekan, Çantay Kitabevi, İstanbul.

TÜIK, (2018). http://www.tuik.gov.tr/Start.do (E.t. 05.03.2019)

UNHCR, (2018). https://www.unhcr.org/tr/unhcr-turkiye-istatistikleri (E.t. 05.03.2019)

Yabancılar ve Uluslararası Koruma Kanunu (2013). TC Resmi Gazete. 28615. 11 Nisan 2013.

Yabancıların Türkiye'de İkamet Ve Seyahatleri Hakkında Kanun, T.C Resmi Gazete, 7564, 24 Temmuz 1950.

Yüceşahin, M. Murat (2017). "Uluslararası Göç, Kimlik Ve Mekânsal Kümelenme-Ayrışma", Süleyman Demirel Üniversitesi İktisadi ve İdari Bilimler Fakültesi Dergisi. 22 (Göç Özel Sayısı): 1303-1315. 